Systemy Logistyczne Wojsk

Zeszyt 54 (2021)

ISSN 1508-5430, s. 5-24

DOI: $10.37055 / \mathrm{slw} / 140374$

Military Logistics Systems

Volume 54 (2021)

ISSN 1508-5430, pp. 5-24

DOI: $10.37055 / \mathrm{slw} / 140374$
Instytut Logistyki

Wydział Bezpieczeństwa, Logistyki i Zarządzania

Wojskowa Akademia Techniczna

w Warszawie

Institute of Logistics

Faculty of Security, Logistics and Management Military University of Technology

in Warsaw

\title{
Evaluation of Selected Elements of the Potential of the Polish Armed Forces
}

\section{Ocena wybranych elementów potencjału Sił Zbrojnych RP}

\author{
Jarosław Kurek \\ jaroslaw.kurek@wat.edu.pl; ORCID: 0000-0003-3633-0821 \\ Military University of Technology
}

\begin{abstract}
The article contains a presentation of the Polish Armed Forces and in-depth characteristics of selected areas, which, in the author's opinion, determine the level of its military potential. The Armed Forces of the Republic of Poland were characterized, focusing on the main defense tasks that are set for soldiers of the Polish Army in the context of fighting and securing the interests of the Polish state, as well as tasks resulting from international agreements. A definition of the Armed Forces potential was showing the approach to this issue by various authors. The number of soldiers was assessed and compared with the strength of the world's most powerful armies as well as the armies of neighboring countries. An analysis of material resources was made, presenting not only their current state, but also the prospects for development. Additionally, it was emphasized that apart from personal and material resources, an extremely important element influencing the military potential is the psychophysical condition of Polish soldiers. It was emphasized that a particularly important feature that should characterize a soldier is high level of physical fitness. In order to understand this problem well, physical fitness has been defined according to the approach of various authors, gross motor skills have been described, broken down into fitness and non-fitness skills, and the method of assessing the physical fitness of soldiers of the Polish Army has been presented. In the last stage, reference was made to the results of the physical fitness assessment presented in the available national literature.
\end{abstract}

Keywords: national security, military potential, psychophysical condition of soldiers, physical fitness, Armed Forces of the Republic of Poland

Abstrakt. W artykule zaprezentowano Siły Zbrojne RP oraz pogłębioną charakterystykę wybranych obszarów, które zdaniem autora determinują poziom potencjału militarnego. Scharakteryzowano Siły Zbrojne Rzeczypospolitej Polskiej, skupiając się na głównych zadaniach obronnych stawianych przed żołnierzami Wojska Polskiego w kontekście prowadzenia walki i zabezpieczenia interesów państwa polskiego, a także zadaniach wynikających z porozumień międzynarodowych. Przedstawiono definicję potencjału Sił Zbrojnych, 
prezentując podejście do tego zagadnienia różnych autorów. Oceniono liczbę żołnierzy Wojska Polskiego z podziałem na korpusy osobowe, rodzaje wojsk i porównano ją z liczebnością najpotężniejszych armii świata, a także armii sąsiadujących. Dokonano analizy posiadanych zasobów materialnych, prezentując nie tylko ich aktualny stan, ale również perspektywy rozwoju. W tym kontekście szczegółowo przedstawiono aktualny stan uzbrojenia Wojsk Lądowych Sił Zbrojnych RP, a także główne uzbrojenie i wyposażenie Sił Zbrojnych RP. Dodatkowo podkreślono, że oprócz posiadanych zasobów osobowych oraz materialnych niezwykle ważnym elementem wpływającym na potencjał militarny jest kondycja psychofizyczna i również w tym kontekście dokonano oceny żołnierzy Wojska Polskiego. W związku z tym scharakteryzowano elementy kondycji psychofizycznej, do której zaliczono zdrowie psychiczne, cechy osobowości oraz sprawność fizyczną. Podkreślono, że szczególnie istotną cechą, która powinna charakteryzować żołnierza, jest wysoki stopień wyszkolenia fizycznego. W celu poprawnego zrozumienia tego problemu zdefiniowano sprawność fizyczną w podejściu różnych autorów, dokonano opisu podstawowych zdolności motorycznych z podziałem na zdolności kondycyjne i niekondycyjne oraz przedstawiono sposób oceny sprawności fizycznej żołnierzy Wojska Polskiego. W ostatnim etapie odniesiono się do wyników oceny sprawności fizycznej przedstawianych w dostępnej literaturze krajowej. W tym ujęciu zaprezentowano podstawowe wyniki badań przeprowadzone m.in. na żołnierzach Wojsk Specjalnych oraz kawalerii powietrznej.

Słowa kluczowe: bezpieczeństwo narodowe, potencjał militarny, kondycja psychofizyczna żołnierzy, sprawność fizyczna, Siły Zbrojne RP

\section{Introduction}

The potential of the Polish Armed Forces as an element of military potential is part of military security. Currently, the Polish Armed Forces are undergoing deep technical and personnel modernization, as evidenced by new arms purchase contracts and ongoing campaigns to increase the size of the army. Therefore, it is reasonable to evaluate selected elements of the Polish Armed Forces in the context of their human and material resources. In addition, during the Covid-19 pandemic, the Polish Armed Forces are combating the effects of the epidemic. The mental and physical condition of the Polish Armed Forces is therefore nowadays an extremely important factor determining their ability to perform tasks, including non-military ones. The topic addressed is therefore timely and closely related to the current situation.

The research problem of the undertaken topic is the assessment of human and material resources of the Polish Armed Forces in the context of technical modernization of the army and increasing its size, and in effect increasing the military potential of Poland. Thus, the purpose of the research is to evaluate selected elements of the Polish Armed Forces' potential. The following statement was adopted as the research hypothesis: The potential of the Polish Armed Forces is being increased in terms of the ongoing technical modernization and increasing the size of the army.

The thesis poses the following research questions:

1. How are the concepts of military security and the Polish Armed Forces' potential understood?

2. How does the current size of the Polish Army compare to the armies of other countries?

3. What kind of weaponry does the Polish Army have?

4. What affects the mental and physical condition of soldiers? 
The following theoretical methods were used to achieve the research objectives: analysis, synthesis, comparison and inference. The article uses open sources of information and own studies. It consists of four parts. The first part presents basic information about military security. Second part shows characteristics of the Polish Armed Forces. Then, the article focuses on potential of the Polish Armed Forces broken down into human and material resources. Last part presents psychophysical fitness and its elements.

\section{Military security}

The traditional interpretation of the term "security" is related to the experiences of World War II, when the main threat was an armed conflict, and the most important element of security was military strength. Therefore, national security was understood as the military defense of a state against a military threat.

After World War II, during the Cold War, security was provided by expanded military capabilities and structures aimed to deter and possibly defend against external threats. The arms race, the lack of democracy, and the constant potential military threat did not address many aspects of national security. It was not until the 1970s and 1980s that a broader understanding of security became widespread, when other aspects began to be taken into account alongside military threats. National security also became increasingly intertwined with economic and political interests.

Nowadays non-military factors, which support and complement military actions, play an increasingly important role in the understanding of security. Concepts are proposed that take into account political, economic, environmental, social and military elements, analyzed in an international context.

The departure from the narrow understanding of security resulted in the concept being understood in two ways: as negative (narrow) and positive (broad) (Serowaniec, Włoch, 2017). The negative understanding means the absence of threats, i.e., an attitude aimed at protection against potential threats, while the positive understanding means a search for new solutions to achieve freedom of development (Olak, Olak, 2016).

One of the types of national security is the military security of the state. Nowadays, two dimensions of security are distinguished based on the origin of the threat - internal and external.

Generally, military security consists of the following elements:

- armed forces - their organization and equipment;

- military alliances and other organizations;

- strategic concepts of utilization of all forces (Wojnarowski, Babula, 2004).

And in such a context, this article evaluates the potential of the Armed Forces of the Republic of Poland. 


\section{Characteristics of the Polish Armed Forces}

The Polish Armed Forces, i.e., the military personnel with armaments and equipment, assigned by the Polish state in order to secure its interests, as well as to carry out combat operations, are the fundamental element of Poland's defense system. The tasks, duties and organization of the Armed Forces are defined by the Constitution of the Republic of Poland, the Act of 21 November 1967 on the Universal Duty to Defend the Republic of Poland, as amended, the National Security Strategy of the Republic of Poland of 2014 and the Defense Concept of the Republic of Poland.

According to the above documents, the main tasks of the Polish Armed Forces, which are to ensure the ability of the Polish state to defend itself and respond to aggression, are:

- maintaining readiness to execute tasks related to defending and protecting the borders;

- conducting strategic defensive operations within the territory of the Republic of Poland;

- participation in anti-terrorist operations both within the country and abroad;

- participation in a defense operation outside the country in accordance with the allied commitments under Art. 5 of the North Atlantic Treaty;

- conducting reconnaissance and intelligence activities (National Security Strategy of the Republic of Poland, 2014).

In addition, the Polish Armed Forces perform tasks in support of internal security subsystems, support participation in operations and crisis management missions (peacekeeping, crisis response, humanitarian assistance) conducted by NATO, EU, $\mathrm{UN}$, and other operations resulting from international agreements, as well as military cooperation in the development and application of confidence-building and security measures (Borucka, Łagowska, 2020). The Polish Armed Forces are to be equipped with defensive and offensive capabilities in the realm of cyberspace to ensure their readiness to conduct protective and defensive operations on a larger scale should a cyberconflict or cyberwar occur (National Security Strategy of the Republic of Poland, 2014). They also must be ready to cooperate with other agencies in crisis management operations, both in Poland and in allied countries.

The potential anticipated to accomplish the above consists of the following types of Armed Forces:

1. Land Forces;

2. Air Force;

3. Navy;

4. Special Forces;

5. Territorial Defense Force. 
The Polish Armed Forces also include the Military Gendarmerie as their separate and specialized force. The Armed Forces consist of military and organizational units. The President of the Republic of Poland is the head of the Polish Armed Forces, while the Minister of National Defense is responsible for their management.

\section{Potential of the Polish Armed Forces}

The potential of the Polish Armed Forces is an element of the military potential of the Polish state. It is defined as part of the war potential, i.e., the military capabilities of the state or coalition appropriate to specific conditions (Przybyło, 1989). It is composed of:

- the number and quality of equipment;

- the organizational and command capabilities;

- the military infrastructure;

- the trained reserves forces;

- the stocks of combat assets and material and technical supplies;

- the capacity to rebuild and expand the armed forces.

In addition, the military potential is conditioned by other elements of war potential, i.e.:

- the economic-defensive potential;

- the moral-political potential;

- the civil defense potential.

Another approach is presented by Miroslaw Sulek, according to whom the military basis of defense potential, which stems from economic and political grounds, is expressed in the ability of the state to neutralize the military efforts of the enemy (alone or in alliance). These capabilities are expressed in the following aspects (Sułek, 1994):

- the number and armament of the armed forces;

- the combat readiness of the armed forces;

- the morale of the soldiers; the advancement of science and art of war;

- the efficiency of command. According to the above, military potential is based on three basic pillars, i.e., economic, military and political.

A different view was presented by Flanek, Kinasiewicz and Urbanek - representatives of the IT community, who placed the meaning of the concept of military potential between the concepts of army potential and war potential. The narrowest understanding of military potential was the sum of the stationary military system defined by the number of soldiers and tactical units. The broader understanding of military potential was army potential expanded to include the military sector of the economy, which included trained reserve forces, war technology reserves, and specialized production capacity. War potential, i.e., military potential plus mobilized human and material 
resources in the system of functioning of the state shifted to focus on war, was placed on the next level. The most broadly understood was the military potential seen as the maximum ability of the state system to provide armed forces and resources for war needs in a relatively short period of time (Falanek, Kinasiewicz, Urbanek, 1997).

Slawomir Sadowski offered his own definition of the term "military potential" as the part of war potential that defines the military capabilities of a state or alliance to transition from a peacetime to a wartime organizational structure, i.e., the state's ability to adapt quickly to wartime conditions. It is composed of:

- the number of soldiers;

- the number of armaments and technical combat and logistics assets;

- the organizational and command capabilities;

- the military infrastructure;

- the trained reserves forces;

- the stocks of combat assets and material and technical supplies;

- the capacity to rebuild and expand the armed forces (Sadowski, 2024, 178).

\section{Human resources of the Polish Armed Forces}

In accordance with the above, the human resources of the Polish Armed Forces were assessed first. The total number of all soldiers in 2018 was 144,142 (https:// archiwum2019.mon.gov.pl/d/pliki/dokumenty/rozne/2018/02/budzet2018.pdf, access $21^{\text {st }}$ April 2021), including:

- 107,704 professional soldiers (https://dane.gov.pl/dataset/1168,dane-kadrowe $/$ resource $/ 23517 /$ table? page $=1$ \&per_page $=20 \& q=\&$ sort $=$, access $27^{\text {th }}$ July 2020);

- $\quad 12,000$ soldiers of the Polish Reserve Forces;

- 5,000 candidates for professional soldiers;

- 24,000 soldiers of the Polish Territorial Defense Force.

The Polish Armed Forces include the following types (The Military Balance 2019, https://archiwum2019.mon.gov.pl/d/pliki/dokumenty/rozne/2018/02/budzet2018. pdf, access $21^{\text {st }}$ April 2021, https://www.prezydent.pl/pierwsza-dama/aktywnosc/ art,735, wizyta-malzonki-prezydenta-w-jednostce-wojskowej-agat.html, access: $22^{\text {nd }}$ July 2020, https://media.terytorialsi.wp.mil.pl/informacje/475688/kolejne-przysiegizolnierzy-wot-formacja-liczy-juz-ponad-24-tys-zolnierzy, access: $22^{\text {nd }}$ July 2020 , https://dane.gov.pl/dataset/1168,dane-kadrowe/resource/23517/table?page=1\&per_ page $=20 \& \mathrm{q}=\&$ sort $=$, access: $27^{\text {th }}$ July 2020 ):

- Land Forces - 61,000 soldiers (2019);

- Air Force - 18,700 soldiers (2019);

- Navy-7,020 soldiers (2018);

- Special Forces - 3,100 soldiers (2020); 
- Territorial Defense Force - 24,000 (2019) including 2,600 professional soldiers;

- Others - 36,025 soldiers.

The breakdown of soldiers according to personnel corps is as follows:

- Officers - 20,614 (1,983 women, 18,631 men);

- Non commissioned officers - 38893 (1 226 women, 37667 men);

- Privates - 48,197 (4,223 women, 43,974 men).

In addition to the above, the Armed Forces include the Military Gendarmerie and the Garrison Warsaw Command, as well as other institutions of the Ministry of Defense.

According to the announcement from the Operations Center of the Ministry of Defense, on 1 February 2020, there were 106.3 thousand soldiers in professional military service (https://www.rp.pl/Wojsko/302189946-MON-ma-problem-Liczbazolnierzy-spada.html, access: $30^{\text {th }}$ April 2020).

Throughout 2020, the Ministry of Defense, according to official announcements, accepted 7 thousand new professional soldiers, thus the number of professional soldiers increased to 110,100 (1). A comparison of the human resources of the Polish Armed Forces and the world's most powerful armies according to the Global Firepower portal is presented in Tab. 1 (Global Firepower - 2021 World Military Strength Rankings).

Table 1. Comparison of the human resources of the Polish Armed Forces and the world's most powerful armies

\begin{tabular}{|c|c|c|c|c|c|}
\hline Demographic factors & Poland & USA & Russia & China & India \\
\hline Population & $38,282,325$ & $332,639,102$ & $141,722,205$ & $1,394,015,977$ & $1,326,093,247$ \\
\hline $\begin{array}{l}\text { Working age } \\
\text { population }\end{array}$ & $\begin{array}{c}18,758,339 \\
(49.0 \%)\end{array}$ & $\begin{array}{c}146,361,205 \\
(44.0 \%)\end{array}$ & $\begin{array}{c}69,443,880 \\
(49.0 \%)\end{array}$ & $\begin{array}{c}752,768,628 \\
(54.0 \%)\end{array}$ & $\begin{array}{c}623,263,826 \\
(47.0 \%)\end{array}$ \\
\hline $\begin{array}{l}\text { Population fit for } \\
\text { military service }\end{array}$ & $\begin{array}{c}15,381,838 \\
(40.2 \%)\end{array}$ & $\begin{array}{c}121,479,800 \\
(36.5 \%)\end{array}$ & $\begin{array}{c}46,527,400 \\
(32.8 \%)\end{array}$ & $\begin{array}{c}617,270,275 \\
(44.3 \%)\end{array}$ & $\begin{array}{c}492,378,423 \\
(37.1 \%)\end{array}$ \\
\hline $\begin{array}{l}\text { Population becoming } \\
\text { of age fit for military } \\
\text { service during the year }\end{array}$ & $\begin{array}{c}461,455 \\
(1.2 \%)\end{array}$ & $\begin{array}{c}4,251,793 \\
(1.3 \%)\end{array}$ & $\begin{array}{c}1,302,767 \\
(0.9 \%)\end{array}$ & $\begin{array}{c}19,752,649 \\
(1.4 \%)\end{array}$ & $\begin{array}{l}23,141,786 \\
(1.7 \%)\end{array}$ \\
\hline $\begin{array}{c}\text { Total number } \\
\text { of military personnel }\end{array}$ & $\begin{array}{c}\text { approx. } \\
193,500 \\
(0.5 \%)\end{array}$ & $\begin{array}{l}\text { approx. } \\
2,245,500 \\
(0.7 \%)\end{array}$ & $\begin{array}{c}\text { approx. } \\
3,014,000 \\
(2.1 \%)\end{array}$ & $\begin{array}{c}\text { approx. } \\
2,695,000 \\
(0.2 \%)\end{array}$ & $\begin{array}{l}\text { approx. } \\
2,600,000 \\
(0.2 \%)\end{array}$ \\
\hline $\begin{array}{c}\text { Active-duty military } \\
\text { personnel }\end{array}$ & $\begin{array}{c}120,000 \\
(0.3 \%) \\
\end{array}$ & $\begin{array}{c}1,400,000 \\
(0.4 \%)\end{array}$ & $\begin{array}{c}1,014,000 \\
(0.7 \%)\end{array}$ & $\begin{array}{c}2,185,000 \\
(0.2 \%) \\
\end{array}$ & $\begin{array}{c}1,445,000 \\
(0.1 \%)\end{array}$ \\
\hline $\begin{array}{c}\text { Reserve force military } \\
\text { personnel }\end{array}$ & $\begin{array}{c}0 \\
(0.0 \%)\end{array}$ & $\begin{array}{c}845,500 \\
(0.3 \%)\end{array}$ & $\begin{array}{c}2,000,000 \\
(1.4 \%)\end{array}$ & $\begin{array}{c}510,000 \\
(0.0 \%)\end{array}$ & $\begin{array}{l}1,155000 \\
(0.1 \%)\end{array}$ \\
\hline $\begin{array}{c}\text { Paramilitary sector } \\
\text { personnel }\end{array}$ & $\begin{array}{l}73,500 \\
(0.2 \%)\end{array}$ & $\begin{array}{c}0 \\
(0.0 \%)\end{array}$ & $\begin{array}{c}550,555 \\
(0.4 \%)\end{array}$ & $\begin{array}{c}660,000 \\
(0.0 \%)\end{array}$ & $\begin{array}{c}2,527,000 \\
(0.2 \%)\end{array}$ \\
\hline
\end{tabular}

Source: https://www.globalfirepower.com, access: $28^{\text {th }}$ January 2021 
Table 2. Comparison of the human resources of the Polish Armed Forces and the armies of neighboring countries - part 1

\begin{tabular}{|c|c|c|c|c|c|}
\hline Demographic factors & Poland & Germany & $\begin{array}{l}\text { Czech Re- } \\
\text { public }\end{array}$ & Slovakia & Ukraine \\
\hline Population & $38,282,325$ & $80,159,662$ & $10,702,498$ & $5,440,602$ & $43,922,083$ \\
\hline Working age population & $\begin{array}{c}18,758,339 \\
(49.0 \%)\end{array}$ & $\begin{array}{c}36,873,445 \\
(46.0 \%)\end{array}$ & $\begin{array}{c}5,030,174 \\
(47.0 \%)\end{array}$ & $\begin{array}{c}2,774,707 \\
(51.0 \%)\end{array}$ & $\begin{array}{c}22,400,262 \\
(51.0 \%)\end{array}$ \\
\hline $\begin{array}{l}\text { Population fit for military } \\
\text { service }\end{array}$ & $\begin{array}{c}15,381,838 \\
(40.2 \%) \\
\end{array}$ & \begin{tabular}{|c|}
$29,498,756$ \\
$(36.8 \%)$ \\
\end{tabular} & $\begin{array}{c}4,074,953 \\
(38.1 \%) \\
\end{array}$ & $\begin{array}{c}2,303,007 \\
(42.3 \%) \\
\end{array}$ & $\begin{array}{c}15,680,184 \\
(35.7 \%) \\
\end{array}$ \\
\hline $\begin{array}{c}\text { Population becoming of age } \\
\text { fit for military service during } \\
\text { the year }\end{array}$ & $\begin{array}{c}461,455 \\
(1.2 \%)\end{array}$ & $\begin{array}{c}796,466 \\
(1.0 \%)\end{array}$ & $\begin{array}{l}97,787 \\
(0.9 \%)\end{array}$ & $\begin{array}{l}62,181 \\
(1.1 \%)\end{array}$ & $\begin{array}{c}470,406 \\
(1.1 \%)\end{array}$ \\
\hline $\begin{array}{c}\text { Total number of military } \\
\text { personnel }\end{array}$ & $\begin{array}{l}\text { ok. } 193,500 \\
\quad(0.5 \%)\end{array}$ & $\begin{array}{c}\text { ok.,215 650 } \\
(0.3 \%)\end{array}$ & $\begin{array}{l}\text { ok. } 25,000 \\
(0.2 \%)\end{array}$ & $\begin{array}{l}\text { ok. } 16,000 \\
(0.3 \%)\end{array}$ & $\begin{array}{c}\text { ok. } 1,155,000 \\
\quad(2.6 \%)\end{array}$ \\
\hline $\begin{array}{l}\text { Active-duty military per- } \\
\text { sonnel }\end{array}$ & $\begin{array}{c}120,000 \\
(0.3 \%)\end{array}$ & $\begin{array}{c}185,000 \\
(0.2 \%)\end{array}$ & $\begin{array}{l}\text { ok. } 25,000 \\
\quad(0.2 \%)\end{array}$ & $\begin{array}{l}16,000 \\
(0.3 \%)\end{array}$ & $\begin{array}{c}255,000 \\
(0.6 \%)\end{array}$ \\
\hline $\begin{array}{l}\text { Reserve force military } \\
\text { personnel }\end{array}$ & $\begin{array}{c}0 \\
(0.0 \%)\end{array}$ & $\begin{array}{l}30,000 \\
(0.0 \%)\end{array}$ & $\begin{array}{c}0 \\
(0.0 \%)\end{array}$ & $\begin{array}{c}0 \\
(0.0 \%)\end{array}$ & $\begin{array}{c}900,000 \\
(2.0 \%)\end{array}$ \\
\hline $\begin{array}{c}\text { Paramilitary sector } \\
\text { personnel }\end{array}$ & $\begin{array}{l}73,500 \\
(0.2 \%)\end{array}$ & $\begin{array}{c}0 \\
(0.0 \%)\end{array}$ & $\begin{array}{c}0 \\
(0.0 \%)\end{array}$ & $\begin{array}{c}0 \\
(0.0 \%)\end{array}$ & $\begin{array}{l}90,000 \\
(0.2 \%)\end{array}$ \\
\hline
\end{tabular}

Source: https://www.globalfirepower.com, access: $28^{\text {th }}$ January 2021

Table 3. Comparison of the human resources of the Polish Armed Forces and the armies of neighboring countries - part 2

\begin{tabular}{|c|c|c|c|c|}
\hline Demographic factors & Poland & Belarus & Lithuania & Russia \\
\hline Population & $38,282,325$ & $9,477,918$ & $2,731,464$ & $141,722,205$ \\
\hline Working age population & $\begin{array}{c}18,758,339 \\
(49.0 \%)\end{array}$ & $\begin{array}{c}5,023,297 \\
(53.0 \%)\end{array}$ & $\begin{array}{c}1,775,452 \\
(50.7 \%)\end{array}$ & $\begin{array}{c}69,443,880 \\
(49.0 \%)\end{array}$ \\
\hline $\begin{array}{l}\text { Population fit for military } \\
\text { service }\end{array}$ & $\begin{array}{c}15,381,838 \\
(40.2 \%)\end{array}$ & $\begin{array}{c}3,717,239 \\
(39.2 \%)\end{array}$ & $\begin{array}{c}1,384,852 \\
(50.7 \%)\end{array}$ & $\begin{array}{l}46,527,400 \\
(32.8 \%)\end{array}$ \\
\hline $\begin{array}{c}\text { Population becoming of age } \\
\text { fit for military service during } \\
\text { the year }\end{array}$ & $\begin{array}{l}46,455 \\
(1.2 \%)\end{array}$ & $\begin{array}{c}100,365 \\
(1.1 \%)\end{array}$ & $\begin{array}{l}38,776 \\
(1.4 \%)\end{array}$ & $\begin{array}{c}1,302,767 \\
(0.9 \%)\end{array}$ \\
\hline $\begin{array}{c}\text { Total number of military } \\
\text { personnel }\end{array}$ & $\begin{array}{l}\text { ok. } 193,500 \\
\quad(0.5 \%)\end{array}$ & $\begin{array}{l}\text { ok. } 335,500 \\
\quad(3.5 \%)\end{array}$ & $\begin{array}{c}\text { ok. } 38,500 \\
(1.4 \%)\end{array}$ & $\begin{array}{c}\text { ok. } 3,014,000 \\
(2.1 \%) \\
\end{array}$ \\
\hline $\begin{array}{c}\text { Active-duty military } \\
\text { personnel }\end{array}$ & $\begin{array}{c}120,000 \\
(0.3 \%) \\
\end{array}$ & $\begin{array}{l}45,500 \\
(0.5 \%) \\
\end{array}$ & $\begin{array}{l}18,500 \\
(0.7 \%) \\
\end{array}$ & $\begin{array}{c}1,014,000 \\
(0.7 \%)\end{array}$ \\
\hline $\begin{array}{l}\text { Reserve force military } \\
\text { personnel }\end{array}$ & $\begin{array}{c}0 \\
(0.0 \%)\end{array}$ & $\begin{array}{c}290,000 \\
(3.1 \%)\end{array}$ & $\begin{array}{l}20,000 \\
(0.7 \%)\end{array}$ & $\begin{array}{c}2,000,000 \\
(1.4 \%)\end{array}$ \\
\hline $\begin{array}{c}\text { Paramilitary sector } \\
\text { personnel }\end{array}$ & $\begin{array}{l}73,500 \\
(0.2 \%)\end{array}$ & $\begin{array}{c}110,000 \\
(1.2 \%)\end{array}$ & $\begin{array}{l}14,500 \\
(0.5 \%)\end{array}$ & $\begin{array}{c}550,555 \\
(0.4 \%)\end{array}$ \\
\hline
\end{tabular}

Source: https://www.globalfirepower.com, access: $28^{\text {th }}$ January 2021 
A comparison of the human resources of the Polish Armed Forces and that of the neighboring countries is presented in Table 2 and Table 3 (Global Firepower 2021 World Military Strength Rankings).

The total number of soldiers of the Polish Army in active duty, according to various sources is approx. 120,000. Poland ranks 37 th in the world in this respect. The country with the world's largest army - China, for comparison, has about 2,185,000 active-duty soldiers, which is about 2,065,000 more than Poland. The size of the army of the Russian Federation, which takes the second place in the ranking of the world's most powerful armies according to the Global Firepower portal, is about 1,014,000. Among Poland's neighboring countries, Germany, Ukraine and Russia have larger armed forces.

\section{Material resources of the Polish Armed Forces}

In recent years, the Polish Armed Forces have undergone deep modernization. Among the purchases made were the Patriot system, Himars rocket launchers and helicopters from the Mielec and Świdnik plants. The "Harpia" program, which is currently in progress, is of key importance for the defense of the Republic of Poland. This program concerns the acquisition of 32 fifth generation F-35 aircraft. "Harpi Szpon" is a new program aimed at strengthening the strike capabilities of fighter aircraft, concerning the design and development of an unmanned stealth aircraft, that is undetectable to radars.

The main directions of development of the Polish Armed Forces are included in the "Plan for Technical Modernization of the Polish Armed Forces for 2021-2035". The plan assumes, in addition to the mentioned "Harpia" and "Harpi Szpon" programs, the development of the following programs:

- F-16 - purchase of additional F-16 aircraft;

- Kruk - acquisition of modern attack helicopters for land forces;

- Obserwator - acquisition of satellites, microsatellites, reconnaissance aircraft and drones, which will collect data to be analyzed at the imaging reconnaissance center and used by soldiers during operations;

- Miecznik - acquisition of coastal defense vessels, in cooperation with the Polish shipbuilding industry;

- Orka - acquisition of surface and underwater target acquisition capabilities by the New Type Submarine;

- Murena - acquisition of light missile vessels at Polish shipyards;

- KTO Rosomak - procurement of transporters in basic and specialized versions;

- Wilk - acquisition of a new generation tank;

- Borsuk - acquisition of an amphibious infantry fighting vehicle; 
- Krab - purchase of Krab gun-howitzers;

- Rak - purchase of Rak self-propelled mortars;

- OTTOKAR Brzoza - acquisition of several dozen tank destroyers for the anti-tank regiment - 24 units are planned by 2035 ;

- Groszek - acquisition of submunition delivery systems automatically reacting to detected objects;

- Gladius - acquisition of unmanned search and strike systems, the so-called "circulating munitions (20 pieces)";

- KRYL - acquisition of a self-propelled gun-howitzer on a wheeled chassis;

- $\quad$ LANGUSTA M (II) - acquisition of 96 field rocket launchers.

In the area of cybersecurity, the Polish Army intends to develop the cyber.mil program, which aims to procure a package of domestically developed tools and software using state-of-the-art Polish cryptographic technologies. The number of the main armament and equipment of the Polish Armed Forces according to the Global Firepower portal is presented in Table 4 (https://radar.rp.pl/modernizacja-silzbrojnych/14902-pmt-na-lata-2021-2035, access: $24^{\text {th }}$ July 2020, Global Firepower - 2021 World Military Strength Rankings).

Table 4. Main armament and equipment of the Polish Armed Forces

\begin{tabular}{|c|c|}
\hline \multicolumn{2}{|c|}{ Land Forces } \\
\hline Tanks & 863 \\
\hline Armored vehicles & 5,125 \\
\hline $\begin{array}{c}\text { Self-propelled } \\
\text { artillery }\end{array}$ & 529 \\
\hline Rocket launchers & 200 \\
\hline
\end{tabular}

\begin{tabular}{|c|c|}
\hline \multicolumn{2}{|c|}{ Air Force } \\
\hline Fighter aircraft & 91 \\
\hline Transport aircraft & 49 \\
\hline Trainer aircraft & 113 \\
\hline $\begin{array}{c}\text { Special purpose } \\
\text { aircraft }\end{array}$ & 9 \\
\hline Helicopters & 207 \\
\hline Attack helicopters & 30 \\
\hline
\end{tabular}

\begin{tabular}{|c|c|}
\hline \multicolumn{2}{|c|}{ Navy } \\
\hline Frigates & 2 \\
\hline Corvettes & 1 \\
\hline Submarines & 3 \\
\hline Patrol vessels & 4 \\
\hline $\begin{array}{c}\text { Minelayer-landing } \\
\text { vessels }\end{array}$ & 25 \\
\hline
\end{tabular}

Source: https://radar.rp.pl/modernizacja-sil-zbrojnych/14902-pmt-na-lata-2021-2035, access: $24^{\text {th }}$ July 2020, https:// www.globalfirepower.com, access: $28^{\text {th }}$ January 2021

Table 4 presents the number of main armament and equipment of the Polish Armed Forces according to the Global Firepower portal. According to the information contained therein, the Polish Armed Forces as at 28 January 2021 had 7,251 units of heavy equipment, including 6,717 units of Land Forces equipment, 499 units of Air Force equipment and 35 units of Navy equipment. The portal lists the Land Forces equipment in the following categories: tanks - 863 units, armored vehicles - 5,125 units, self-propelled artillery - 529 units, and rocket launchers - 200 units. Air Force equipment was divided into the following categories: fighter aircraft - 91 items, transport aircraft - 49 items, trainer aircraft - 113 items, special purpose aircraft - 9 items, helicopters - 207 items, attack helicopters - 30 items, whereas the 
Navy equipment was listed in the following categories: frigates -2 items, corvettes - 1 item, submarines - 3 items, patrol vessels - 4 items, minelayer-landing vessels - 25 items. Detailed data on the armament of the Polish Armed Forces are presented in Table 5 (Kijewski, 2021).

Table 5. Armaments of Land Forces of the Polish Armed Forces

\begin{tabular}{|c|c|c|c|}
\hline Hardware name & Code mark & $\begin{array}{c}\text { Number } \\
\text { (in use / in reserve) }\end{array}$ & $\begin{array}{c}\text { Year } \\
\text { of introduction }\end{array}$ \\
\hline $\begin{array}{c}23 \mathrm{~mm} \text { towed anti-aircraft cannon } \\
\text { ZU-23-2 / Hibneryt }\end{array}$ & - & $234 / 152$ & 1966 \\
\hline $\begin{array}{l}\text { Gun and missile anti-aircraft towed } \\
\text { system ZUR-23-2S / Hibneryt }\end{array}$ & JOD & $43 / 8$ & 1988 \\
\hline $\begin{array}{c}\text { Gun and missile anti-aircraft towed } \\
\text { system ZUR-23-2PG }\end{array}$ & JODEK & 75 & 2002 \\
\hline $\begin{array}{l}23 \mathrm{~mm} \text { self-propelled anti-aircraft } \\
\text { cannon ZSU-23-4 }\end{array}$ & SZYŁKA & 20 & 1967 \\
\hline $\begin{array}{l}\text { Gun and missile self-propelled } \\
\text { anti-aircraft system ZSU-23-4MP }\end{array}$ & BIAŁA & 21 & 2005 \\
\hline $\begin{array}{l}57 \mathrm{~mm} \text { towed anti-aircraft cannon } \\
\text { S-60M }\end{array}$ & - & $0 / 83$ & 1958 \\
\hline $\begin{array}{l}57 \mathrm{~mm} \text { towed anti-aircraft cannon } \\
\text { S-60MB }\end{array}$ & - & 32 & 1996 \\
\hline $73 \mathrm{~mm}$ portable recoilless gun SPG-9 & - & 203 & 1968 \\
\hline $84 \mathrm{~mm}$ recoilless gun & CARL GUSTAF & 24 & 1997 \\
\hline $\begin{array}{c}60 \mathrm{~mm} \text { portable mortar LM-60D } \\
\text { and LM-60K }\end{array}$ & PLUTON & $268+108=376$ & 1999 \\
\hline $60 \mathrm{~mm}$ portable mortar LRM 99 pattern & ANTOS & $<200$ & 2010 \\
\hline $98 \mathrm{~mm}$ towed mortar M-98 & RAD & 96 & 2003 \\
\hline $\begin{array}{l}120 \mathrm{~mm} \text { towed mortar } 1938 / 85 / \\
1943 / 85 \text { pattern }\end{array}$ & pattern & $22 / 117$ & 1943 \\
\hline $\begin{array}{l}120 \mathrm{~mm} \text { towed mortar } 2 \mathrm{~B} 11 \\
\text { to } 2 \mathrm{~S} 12 \text { SANI set }\end{array}$ & SANI & 15 & 1984 \\
\hline $120 \mathrm{~mm}$ self-propelled mortar & RAK & $\begin{array}{c}8 \times 8=64 \\
\text { (ultimately } 82 \text { ) }\end{array}$ & 2017 \\
\hline $85 \mathrm{~mm}$ towed division cannon D-44 & - & $0 / 20$ & 1956 \\
\hline 122 self-propelled howitzer $2 \mathrm{~S} 1 \mathrm{~T} / 2 \mathrm{~S} 1$ & GOŹDZIK & $180+199=379$ & 1974 \\
\hline $\begin{array}{l}122 \mathrm{~mm} \text { self-propelled rocket launcher } \\
\text { BM-21 }\end{array}$ & - & 93 & 1966 \\
\hline $\begin{array}{c}122 \mathrm{~mm} \text { self-propelled rocket launcher } \\
\mathrm{RM}-70 / 85\end{array}$ & - & 30 & 1986 \\
\hline
\end{tabular}


cd. tab. 5

\begin{tabular}{|c|c|c|c|}
\hline Hardware name & Code mark & $\begin{array}{c}\text { Number } \\
\text { (in use / in reserve) }\end{array}$ & $\begin{array}{c}\text { Year } \\
\text { of introduction }\end{array}$ \\
\hline $\begin{array}{l}122 \text { self-propelled rocket launcher } \\
\text { WR-40 }\end{array}$ & LANGUSTA & 75 & 2006 \\
\hline $\begin{array}{l}152 \mathrm{~mm} \text { self-propelled howitzer } \\
\text { wz.1977 }\end{array}$ & DANA & 111 & 1983 \\
\hline $155 \mathrm{~mm}$ self-propelled howitzer & KRAB & $\begin{array}{c}64 \\
\text { (ultimately120) }\end{array}$ & $2012 / 2017$ \\
\hline $\mathrm{T}-72 \mathrm{M} / \mathrm{M} 1 \operatorname{tank}$ & - & 543 & 1977 \\
\hline PT-91 tank & TWARDY & 91 & 1994 \\
\hline PT-91M tank & TWARDY & 141 & 1987 \\
\hline Leopard 2A4 tank & - & $128+14=142$ & $2002 ; 2014$ \\
\hline Leopard 2A5 tank & - & 105 & 2014 \\
\hline Infantry fighting vehicle BWP-1 & - & 1297 & 1973 \\
\hline $\begin{array}{l}\text { Reconnaissance combat vehicle } \\
\text { BWR-1D / 1Dm and BWR-1S / 1Sm }\end{array}$ & - & $19 / 3+14 / 2$ & $1984 / 2019$ \\
\hline $\begin{array}{l}\text { Reconnaissance combat vehicle } \\
\text { BRDM-2 }\end{array}$ & - & 270 & 1966 \\
\hline $\begin{array}{c}\text { Reconnaissance combat vehicle } \\
\text { BRDM-2M96 }\end{array}$ & - & 70 & 1997 \\
\hline $\begin{array}{c}\text { Reconnaissance combat vehicle } \\
\text { BRDM-2M96iK }\end{array}$ & SZAKAL & 58 & 1997 \\
\hline $\begin{array}{c}\text { Reconnaissance combat vehicle } \\
\text { BRDM-2A }\end{array}$ & ŻBIK-A & 8 & 2001 \\
\hline $\begin{array}{l}\text { Reconnaissance combat vehicle } \\
\text { BRDM-2B }\end{array}$ & ŻBIK-B & 59 & 1998 \\
\hline $\begin{array}{l}\text { Wheeled armored personnel carrier } \\
\text { (HITFIST-30P) }\end{array}$ & ROSOMAK & ca. 315 & 2005 \\
\hline $\begin{array}{l}\text { Wheeled armored personnel carrier } \\
\text { (HITFIST-30P) }\end{array}$ & ROSOMAK-M1 & 119 & 2005 \\
\hline $\begin{array}{l}\text { Wheeled armored personnel carrier } \\
\text { with a turntable OSS-M }\end{array}$ & ROSOMAK-M2 & 6 & 2007 \\
\hline $\begin{array}{l}\text { Wheeled armored personnel carrier } \\
\text { with a turntable OSS-D }\end{array}$ & ROSOMAK-M3 & 31 & 2007 \\
\hline
\end{tabular}

Source: Own study 
Table 5 presents a detailed list of Land Forces equipment, according to which the equipment the Polish Armed Forces use varies in age.

The number of individual types of equipment is as follows: anti-aircraft equipment - 508 units, recoilless guns - 227 units, mortars - 709 units, cannons - 20 units, self-propelled artillery - 602 units, rocket launchers - 198 units, tanks - 1,022 units, armored vehicles $-2,266$ units.

\section{Psychophysical fitness and its elements}

Apart from human and material resources, an extremely important element influencing the military potential is the psychophysical fitness of soldiers. Psychophysical fitness of soldiers of the Polish Army will be characterized below.

\section{Mental health}

Mental fitness is affected by a number of factors. One of them is mental health. It is a difficult concept to define (Heszen-Niejodek, Sęk, 2007; Kasperek-Golimowska, 2004). There are two interpretations of the concept of mental health, negative, i.e., the absence of mental illnesses and disorders, and positive, which sees it as an element of holistic health, meaning the mental potential which enables the individual to satisfy their needs, achieve successes, take joy and satisfaction from life, increase the ability to develop, learn, cope with changes and overcome difficulties, as well as foster the establishment and maintenance of good relationships with people and active participation in social life (Tabak, 2014).

K. Dąbrowski defined mental health as the ability to develop towards a comprehensive understanding, experiencing, discovering and creating an ever-higher hierarchy of reality and values up to a specific individual and social ideal (Dąbrowski, 1985). The concept of mental health comprises emotional health (ability to recognize feelings, express them in a way adequate to the situation, providing a sense of comfort and social acceptance, ability to cope with difficulties, stress, tension, anxiety, depression, aggression) and intellectual health (ability to think logically, clearly, coherently, learn, realize intellectual potential) (Woynarowska, 2007).

Mental health is described through negative and positive indicators, which have a quantitative or qualitative dimension. Negative indicators are the quantitative data related to the extent of occurrence of specific health problems, while positive indicators are the data (quantitative and qualitative) resulting from the evaluation of various dimensions of quality of life, human functioning and its properties, e.g., emotional well-being, satisfaction, contentment with various areas of life, manifestation of personal traits or life skills known to correlate positively with well-being 
- dispositional optimism, proactive strategies of coping with stress. Positive indicators stem mainly from psychological and sociological research (Makowska, Poprawa, 1996; Ostrowska, 2004; Woynarowska, 2001).

Maria Jahoda distinguished the following positive indicators of mental health: positive and high self-esteem, strong sense of identity, ability to develop and self-actualize, ability to integrate experiences, autonomy - the ability to be independent of social influences and to self-regulate, realistic perception of reality, coping with demands, ability to adapt in a changing world (Woynarowska, 2007).

\section{Personality traits}

The psychophysical fitness of soldiers is also strongly identified with their personality traits. Desirable attributes of a professional soldier of the Polish Armed Forces have been described, i.a., in the Honor Code of professional soldiers of the Polish Army established by the Minister of National Defense Notice on 3 March. According to this document, military service requires discipline, loyalty and sacrifice from soldiers. A professional soldier should possess virtues such as patriotism, valor, honesty, responsibility, righteousness, truthfulness and professional solidarity. A soldier should be characterized by sincerity and respect for others. The Code lists acts that are particularly unworthy of a soldier. These include: betrayal of the Homeland, cowardice on the battlefield, hypocrisy, putting one's self-interest over the common good and failure to fulfill assumed duties. Soldiers' generosity is expressed by readiness to sacrifice their lives in defense of the country, while raising professional qualifications shows their ambition. On the battlefield, a soldier should be characterized by valor, courage and prudence. Outside the service they should be characterized by high standards of conduct and good manners.

\section{Physical fitness}

Physical fitness is a particularly important feature associated with soldiers. This concept continues to be defined by various theorists dealing with physical culture in its broadest sense. Z. Gilewicz described physical fitness as "the readiness of the human body to undertake and solve difficult movement tasks in various life situations, requiring strength, speed, flexibility, agility and endurance, as well as certain acquired and formed skills and habits of movement based on appropriate motor aptitudes and health" (Gilewicz, 1964, pp. 3-31). According to R. Przewęda "physical fitness is a specific ability to perform various forms of movement, determined by the level of development, motor characteristics (skills), morphological, physiological and mental functions" (Przeweda. 1993, p.311). A relatively new concept of training in 
physical fitness was presented by W. Osiński (2003, pp. 19-23) as Health-Related Fitness (H-PF), i.e. health-oriented fitness.

Despite some discrepancies in understanding the concept of physical fitness, some common features, reported by multiple authors, can be distinguished. Physical fitness is therefore connected with the ability to perform specific motor tasks and with human motor skills.

Physical fitness can be divided into general physical fitness (comprehensive) and special physical fitness.

The level of physical fitness is determined by motor abilities. According to Szopa, these determine the body's present state of readiness to perform various types of motor tasks. They are a phenotype of the state of certain predispositions (determined genetically) and environmental influences (Szopa, 1988, Szopa, 1996).

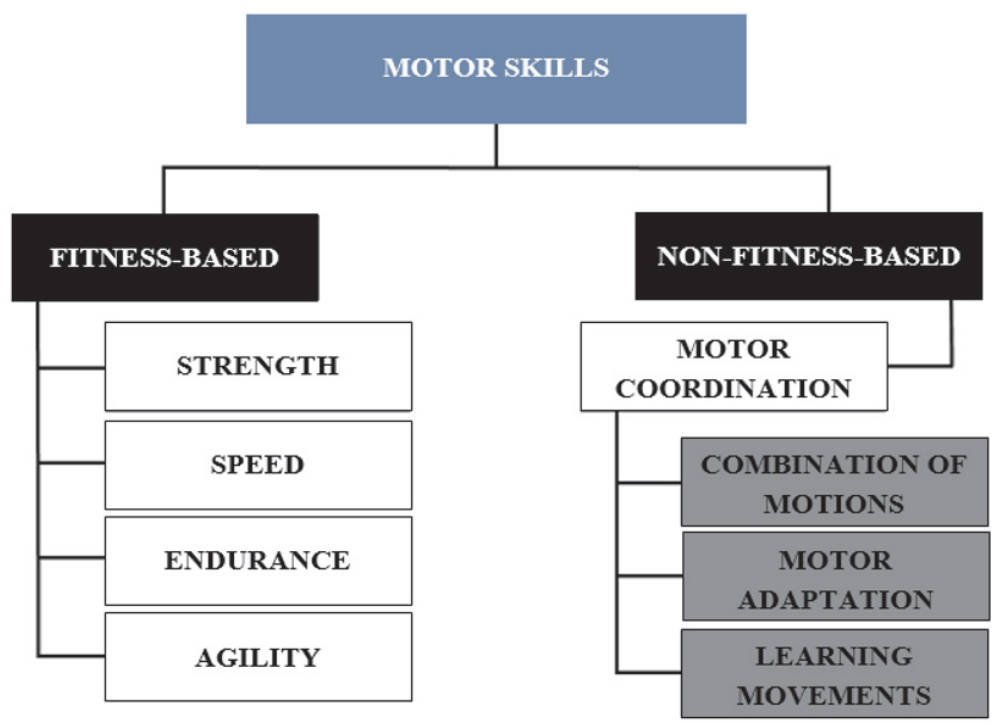

Fig. 1. Fundamental motor abilities

Source: Szopa, 1988, Szopa, 1996

Human strength is the ability to overcome or counteract external resistance through muscular effort (Szopa, 1996; Zaciorski, 1970).

Speed is the degree of ability to move the whole body or its specific parts in space in the shortest possible period of time. The performed task should not cause fatigue which decreases the speed of movement. The exercise time should not exceed 30 seconds, however it is usually much shorter (Osiński, 2003).

Endurance motor skills are abilities to resist fatigue and the ability to perform specific work for a long period of time. In a typical endurance exercise, the work 
should last at least 4 minutes and its intensity should vary between $60-80 \%$ of the maximum (Heyward, 1997; Wuest, Bucher, 1991). Flexibility is the range of motion in a single joint or several joints (Borms, Van Roy, 1996). Coordination (agility) is the ability to integrate movements of different types into a single whole and the ability to quickly switch from one motor activity to another (Wuest, Bucher, 1991).

\section{Psychophysical fitness of the soldiers of the Polish Armed Forces}

Psychophysical fitness of the soldiers of the Polish Armed Forces is a particularly important element of the potential of Poland's Military Security. It is verified as early as at the recruitment stage for military service. According to the Act of 11 September 2003 on professional military service (version in force as at 11 October 2019) (Art. 2), a professional soldier may be a person who holds the appropriate qualifications and is of adequate physical and mental fitness to perform professional military service, which is determined by a military medical commission and confirmed by a ruling issued by the commission in this regard (Act of 11 September 2003) on professional military service (version in force as at 11 October 2019).

Then this fitness is verified annually during a physical fitness test for professional soldiers. The test is conducted on the basis of the Regulation of the Minister of National Defense on conducting physical fitness test for professional soldiers. This regulation has been amended twice in recent years. In 2021, the document dated 2 December 2020 is in force, which defines the conditions and procedure of testing, scope of the exercises, procedure for exemption and other aspects of conducting the verification of physical fitness of professional soldiers. Soldiers are tested in four disciplines:

1. $3000 \mathrm{~m}$ cross-country run or continuous swimming for 12 minutes;

2. pull-ups on a high bar or push-ups, lying face-down on a gym bench;

3. $10 \times 10 \mathrm{~m}$ shuttle run or zigzag run;

4. forward bends for 2 minutes.

Physical fitness rating will be based on the number of points obtained in these four tests, with a maximum of 100 points.

The issue of physical fitness of soldiers in terms of drawing conclusions for the development of new physical fitness tests for soldiers of the Polish Army, as well as expanding knowledge about the importance of physical fitness in the modern Polish Armed Forces was addressed in 2014 by Gen. Franciszek Kochanowski, who at the time was the Chief of the P7 Training Board of the General Staff of the Polish Army. Experiences in this regard were exchanged during the conference entitled "Physical fitness of soldiers in terms of the needs of the operating environment of the Polish Armed Forces in the 21st century" (orig. title - Sprawność fizyczna żotnierzy $w$ warunkach potrzeb środowiska działania Sił Zbrojnych RP w XXI wieku). 
During the conference, it was stated that the physical fitness of soldiers of the Polish Armed Forces has been shaping at different levels over the last 20 years. The highest average rating from the test was obtained by the 50 -year-olds: in group VIII (over 55 years of age) -4.47 and in group VII (51-55 years of age) -4.40 , and the lowest by the youngest soldiers: in group I (up to 25 years of age) -4.10 and in group II (31-35 years of age) - 4.14. The average rating of physical fitness of female soldiers during this period was 4.50 and increased by 0.11 ratings compared to 2012 .

Among the motor skills tested, the highest rated in men was abdominal strength - 4.56 (93.4\% of positive ratings), while the weakest locomotor endurance tested by $3000 \mathrm{~m}$ run -3.65 (69.7\% of positive ratings), doing push-ups on a bench -3.80 ( $86.3 \%$ of positive ratings). Among female soldiers, the best ability was speed and agility tested by the zigzag run -4.70 , while the weakest was arm muscle strength tested by doing push-ups -4.11 .

A negative phenomenon observed during the implementation of the test was the increasing number of sick leaves. In 2014, it concerned $17.1 \%$ of the Armed Forces personnel (in $2012-12.1 \%$ ). The reason for this is probably the great ease of obtaining sick leave by soldiers exempting them from physical education classes and physical fitness tests (http://polska-zbrojna.pl/home/articleshow/12618?t=Zo lnierz-musi-byc-sp, access: $7^{\text {th }}$ January 2020).

In 2013, the assessment of physical fitness of soldiers of Special Forces Unit No. 2305 - "GROM" was conducted by Andrzej Tomczak, Jerzy Bertandt, Anna Kłos and Bartosz Bertrandt. Their analysis indicates that the level of physical fitness of Special Forces soldiers is at an excellent level. In the test of endurance $-3000 \mathrm{~m}$ run, the soldiers reached an average time of 11:57 $\mathrm{min}$, in the test of abdominal muscles - doing forward bends for 2 min they reached an average of 91.5 repetitions, in the test of arm and shoulder muscles strength - doing pull-ups on a high bar - 18.27 repetitions, while in the test of speed and agility $-10 \times 10 \mathrm{~m}$ shuttle run, the average time was $28.8 \mathrm{~s}$ (Tomczak, et al., 2014).

In 2019, the level of physical fitness and nutritional status of air cavalry soldiers were verified by Andrzej Tomczak, Dariusz Jaciubek, Anna Kłos, Izabela Bolczyk and Jerzy Bertrandt. The test covered 400 male soldiers. In the $3000 \mathrm{~m}$ run, the participants reached an average time of 14:00 $\mathrm{min}$, in the pull-up test they reached an average of 14.5 repetitions, in the forward bends test - an average of 62.4 repetitions, while in the $10 \times 10 \mathrm{~m}$ shuttle run - an average of $29.5 \mathrm{~s}$ (Tomczak, Jaciubek, Kłos, et al., 2019).

\section{Final thoughts}

The Armed Forces are a fundamental element of the defense system of the Republic of Poland. At present, they consist of approx. 120,000 soldiers in active duty, and their growth in recent years is clearly noticeable (in 2020 by $5.83 \%$ ). 
In terms of numbers, the Polish Army ranks 37th in the world. In recent years, in addition to an increase in the number of soldiers, there has also been a deep technical modernization of the Polish Army. Increase in expenditure on national defense contributed to the development of key programs for technical modernization of the Polish Armed Forces, such as the purchase of the Patriot system, Himars missile launchers or the fifth generation F-35 aircraft.

Physical fitness of soldiers and promotion of a healthy lifestyle among soldiers were highlighted next to the culture of combat readiness and training of reserves as priority areas of activity for the General Staff of the Polish Army in 2020. High level of physical fitness of Polish soldiers, as one of the basic requirements, is an indicator of the quality of the armed forces, which was emphasized by the Chief of the General Staff - Gen. Rajmund Andrzejczak. Proper diet and physical activity are determinants of a healthy lifestyle, which translates directly into their tactical abilities and high and long-term combat readiness. The determinants of physical fitness of professional soldiers are also the results of the annual physical fitness test. These results, according to various studies, are at a different level depending on the type of the Armed Forces.

In conclusion, it should be stated that the purpose of the research has been achieved. The thesis evaluates what the author believes are the important elements of the Polish Armed Forces' potential. Therefore, the hypothesis that this potential is being increased in terms of ongoing technical modernization and increasing the size of the Army has been confirmed.

The article concerns the review of the current knowledge and provides only direction for further analyzes. Moreover, it is the basis for planned research, selection of methods and possible results.

\section{BIBLIOGRAPHY}

[1] Borucka, A., Łagowska, E., (2020). The role of Polish Armed Forces in the fight against epidemiological threats (SARS-Cov-2). European Research Studies Journal, Volume XXIII, Special Issue 3, 33-46.

[2] DĄвrowski, K., (1985). Zdrowie psychiczne. Warszawa: Wydawnictwo Naukowe PWN.

[3] Flanek, Cz., Kinasiewicz, M., Urbanek, M., (1997). Model potencjału obronno-gospodarczego i militarnego. Warszawa, 60-61.

[4] Gilewicz, Z., (1964). Teoria wychowania fizycznego. Warszawa: PWN, 3-31.

[5] Global Firepower - 2021, World Military Strength Rankings [online]. Dostępne pod adresem: https://www.globalfirepower.com [dostęp: 28 stycznia 2021].

[6] Heszen-Niejodek, I., SęK, H., (2007). Psychologia zdrowia. Warszawa: PWN.

[7] KAspereK-Golimowska, E., (2004). Zdrowie psychiczne. [w:] DROZDOWICZ, Z., (red.), (2005). Europa, Europa. Przewodnik encyklopedyczny po współczesnej Europie, T. 3. Poznań: Wydawnictwo Kurpisz S.A. 
[8] Kochanowski, F., (2014). Żołnierz musi być sprawny [online]. Polska Zbrojna. Dostępne pod adresem: http://polska-zbrojna.pl/home/articleshow/12618?t=Zolnierz-musi-byc-sp [dostęp: 7 stycznia 2020].

[9] Kozubal, M., (2020). MON ma problem. Liczba żołnierzy spada [online]. Rzeczpospolita. dostępne pod adresem: https://www.rp.pl/Wojsko/302189946-MON-ma-problem-Liczba-zolnierzy-spada. html [dostęp: 30 kwietnia 2020].

[10] Lentowicz, Z.,(2019). MON obiecuje wyścig zbrojeń za 500 miliardów złotych [online]. Radar rp.pl. Dostępne pod adresem: https://radar.rp.pl/modernizacja-sil-zbrojnych/14902-pmt-na-lata-2021-2035 [dostęp: 24 lipca 2020].

[11] Makowska, H., Poprawa, R., 1996. Radzenie sobie ze stresem w procesie budowania zdrowia. Elementy psychologii zdrowia. Wrocław: Wydawnictwo Uniwersytetu Wrocławskiego.

[12] MON (2020). Liczba żotnierzy zawodowych z podziałem na korpusy [online]. Dostępne pod adresem:https://dane.gov.pl/dataset/1168,dane-kadrowe/resource/23517/table?page=1\&per_page $=20 \& q=\&$ sort $=$ [dostęp: 27 lipca 2020].

[13] Olak, K., OlaK, A., (2016). Współczesne rozumienie bezpieczeństwa narodowego. Acta Scientifica Academiae Ostroviensis. Sectio A. Nauki Humanistyczne, Społeczne i Techniczne 7(1), 467-480.

[14] Osıński, W., (2003). Antropomotoryka. Poznań: Akademia Wychowania Fizycznego im. Eugeniusza Piaseckiego w Poznaniu, 19-23.

[15] Ostrowska, A., (2004). Społeczeństwo ryzyka? Zagrożenia dla zdrowia psychicznego, [w:] Domański, H., Ostrowska, A., Rychard, A., (red.), (2004). Niepokoje polskie, Warszawa: IFiS PAN, 121-141.

[16] Pietrzak, M., (2019). Kolejne przysięgi żotnierzy WOT, formacja liczy już ponad 24 tys. żołnierzy [online]. Wojska Obrony Terytorialnej. Dostępne pod adresem: https://media.terytorialsi.wp.mil. pl/informacje/475688/kolejne-przysiegi-zolnierzy-wot-formacja-liczy-juz-ponad-24-tys-zolnierzy [dostęp 22 lipca 2020].

[17] PREZYDENT.PL (2020). Wizyta Małżonki Prezydenta w Jednostce Wojskowej AGAT [online]. Dostępne pod adresem: https://www.prezydent.pl/pierwsza-dama/aktywnosc/art,735, wizytamalzonki-prezydenta-w-jednostce-wojskowej-agat.html [dostęp: 22 lipca 2020].

[18] PrzewęDA, R., (1981). Rozwój somatyczny i motoryczny. Warszawa: WSiP, 311.

[19] Przybyєo, A., (1989). Ekonomia obrony. Kraków, 18-21.

[20] Serowaniec, M., WŁoch, W., (2017). Kategoria bezpieczeństwa w ujęciu prawno-filozoficznym. Studia Iuridica Toruniensia, 18, 161-182.

[21] Strategia Bezpieczeństwa Narodowego Rzeczypospolitej Polskiej (2014). Warszawa: BBN, 32.

[22] Szopa, J., (1988). Nowa koncepcja klasyfikacji i struktury motoryczności człowieka. Antropomotoryka. Nr 2, 3-7.

[23] Szopa, J., (1996). Uwarunkowania, przejawy i struktura motoryczności. Kraków: AWF.

[24] ТАвак, I., (2014). Zdrowie psychiczne dzieci i młodzieży. Wsparcie dzieci i młodzieży w pokonywaniu problemów. Studia BAS, Nr 2 (38), 113-138.

[25] Tomczak, A., Bertrandt, J., KŁos, A., Bertrandt, B., (2014). Assessment of physical fitness, physical capacity and nutritional status of soldiers serving in the "GROM" Polish Special Forces. Unit. Probl Hig Epidemiol, 95(1), 86-90.

[26] Tomczak, A., Jaciubek, D., KŁos, A., Bolczyk, I., Bertrandt, J., (2019). Poziom sprawności fizycznej oraz stan odżywienia żołnierzy kawalerii powietrznej. Probl Hig Epidemiol, 100(1), $36-41$. 
[27] Ustawa z dnia 11 września 2003 r. o służbie wojskowej żołnierzy zawodowych (Dz.U. 2003 Nr 179, poz. 1750) (wersja od 11 października 2019), rozdział 1, art. 2 i 5.

[28] Wojnarowski, J., Babula, J., (2004). Bezpieczeństwo militarne Rzeczypospolitej Polskiej. Warszawa: AON.

[29] Woynarowska, B., (2007). Edukacja zdrowotna. Podręcznik akademicki. Warszawa: Wydawnictwo Naukowe PWN.

[30] Woynarowska, B., (2001). Podejście ukierunkowane na rozwój umiejętności życiowych i możliwości jego wykorzystania w edukacji zdrowotnej. Teoretyczne podstawy edukacji zdrowotnej. Stan i oczekiwania. Warszawa: KOWEZ.

[31] ZACIORSKI, W.M., (1970). Kształcenie cech motorycznych sportowca. Warszawa: Sport i Turystyka.

[32] Załącznik do Obwieszczenia Ministra Obrony Narodowej z dnia 3 marca 2008 r. (poz. 55), (Dz.U. MON z 2008 r. Nr 5). Kodeks honorowy żołnierza zawodowego Wojska Polskiego. 